\title{
Seasonal variations in some reproductive parameters of dorper rams in Hungary
}

\author{
Csilla Budai ${ }^{1}$ - János Oláh ${ }^{1}$ - István Egerszegi ${ }^{2}$ - András Jávor ${ }^{1}$ - András Kovács ${ }^{1}$ \\ ${ }^{1}$ University of Debrecen Centre for Agricultural and Applied Economic Sciences Faculty of Agricultural and Food Sciences and \\ Environmental Management, Institute of Animal Science, Biotechnology and Nature Conservation, Debrecen \\ ${ }^{2}$ Institute for Animal Breeding and Nutrition, Herceghalom \\ budaics@agr.unideb.hu
}

\section{SUMMARY}

The purpose of the present study was to test the hypothesis that season has an affect on semen quality and scrotal circumference of Dorper rams. The experiment was carried out with six Dorper rams aged between 15 and 18 month. Semen samples were collected with artificial vagina and volume, concentration $\left(x 10^{9} / \mathrm{ml}\right)$, total sperm number/ejaculate $\left(\times 10^{9}\right)$, mass motility (0-5), progressive motility (\%), scrotal circumference $(\mathrm{cm})$ was observed. Significant differences $(P<0.05)$ were observed in concentration, total sperm number/ejaculate, scrotal circumference in different seasons. Volume was the highest in autumn $(1.4 \pm 0.5 \mathrm{ml})$ and the lowest in the spring (1.3 $\pm 0.4 \mathrm{ml})$. Concentration of semen was lower in spring $\left(2.6 \pm 1.5 \times 10^{9}\right)$ and summer $\left(3.3 \pm 1.5 \times 10^{9}\right)$ as compared to fall $\left(4.1 \pm 1.1 \times 10^{9}\right)(P<0.05)$. Regarding total sperm number/ejaculate $\left(x 10^{9}\right)$, scrotal circumference $(\mathrm{cm})$ all the seasons differed significantly $(P<0.05)$, although the season had no effect on mass motility and progressive individual motility $(P<0.05)$. In conclusion the present study showed that semen quality parameters and scrotal circumference of Dorper rams were better in autumn than in the other sea-sons.

Keywords: sheep, ram, dorper, semen characteristics, season

\section{ÖSSZEFOGLALÁS}

A szerzök azt vizsgálták, hogy az évszakok változása hatással van-e dorper kosok ondójának mennyiségére, sürüségére, motilitására, herekörméretére. A kisérlet során hetente egy alkalommal történt mühüvelyes spermavétel és kéthetente herekörméret (cm) mérés. Spermavételt követöen az ondó mennyisége (ml), koncentrációja (x 109), a spermiumok tömegmozgása (0-5), motilitása (\%), összspermiumszám (x 109)

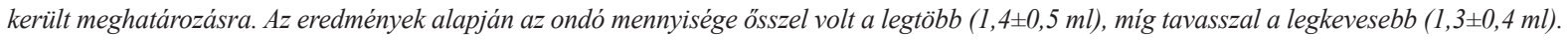
Az ejakulátumban lévö spermiumok koncentrációja mind tavasszal (2,6 $\left.\pm 1,5 \times 10^{9}\right)$ mind nyáron $\left(3,3 \pm 1,5 \times 10^{9}\right)$ alacsonyabb volt az öszi $\left(4,1 \pm 1,1 \times 10^{9}\right)$ időszakban mért eredményhez viszonyitva $(P<0,05)$. Az évszakok változása szerint szignifikáns eltérés volt az összspermiumszámban és a herekörméretben is, viszont a spermiumok tömegmozgására és motilitására nem nem volt hatással az évszakok változása. Összefoglalásként elmondható, hogy az évszakok változásának nincs negativ hatása a dorper kosok ondóminöségére.

Kulcsszavak: juh, kos, dorper, sperma jellemzői, évszak

\section{INTRODUCTION}

Dorper is a mutton sheep developed for the arid regions of South-Africa between 1945-1950, in order to improve the carcass size and quality. The breed was established through the crossing of Blackhead Persian ewes with Dorset Horn rams. The breed performs well even in the semi-arid area and has a really long breeding season which is not seasonally limited (Lategan, 2004). It is a very successful and adaptable breed, that has been exported worldwide from extreme cold to tropical and desert conditions. Recently the number of Dorpers exceeds 10 million heads in the Republic of SouthAfrica. In the past twenty years Dorper has become popular in the Middle-East, China, Canada, Australia, South-America, Mexico and the United States of America. The breed was introduced to Hungary in 2007. Eventually Dorper is one of the most fertile of the sheep breeds with $150 \%$ lambing percentage resulting in $2.25 \mathrm{lambs} /$ year, as the breeding interval can be shortened to 8 months or 3 times in 2 years. Lambs mature early and may be mated at around 9 month of age. Running the rams with ewes continuously all over the year can be an option to increase the sale number of lambs born out of season is an important possibility (Milne, 2000; Kovács et al., 2008; Székely, 2011). Generally rams are one of the key resources for improving quality meat production. Thus it is important to keep the semen production, quality under control all over the year. In sheep testicular size and semen production has been shown to be influenced by nutrition (intake of protein/ energy) and season (Evans and Maxwell, 1987). It is clear from the literature that annual variation in daily photoperiod is the main factor affecting the seasonality in sheep. Decreasing daylight enhances spermiogenesis and scrotal circumference, which is strongly related to semen production capacity of the ram. It is usually larger in the fall breeding season and can decrease by 2-3 cms in the spring (Horváth, 1983; Gergátz, 2007). Some breeds (e.g. Dorset, Merino, Finnsheep, Romanov and hairsheep, like Somali) are much less seasonal in their breeding behaviour, though rams are less affected than ewes (Net 1). Seasonality of reproductive function was observed in rams of certain breeds, like Chios and Friesian (Karagiannidis et al., 2000), Finnish Landrace and Tasmanian Merino (Islam and Land, 1977), Persian Karakul (Kafi et al., 2004), Texel, Suffolk, Ile de France (Mandiki et al., 1998). In Hungary it has been studied in several breeds including British Milk Sheep (Sarlós and Molnár, 1995), Awassi, Barbados Blackbelly, Tsigai, Ile de France, Suffolk, Prolific Merino (Oláh, 2010), Black Variety of the Hungarian Racka (Egerszegi et al., 2011). The purpose of our study was to determine the effect of seasonal fluctuation on 
seminal characteristics, testicular size in mature Dorper rams under the Eastern-Hungarian climatic conditions.

\section{MATERIALS AND METHODS}

\section{Animals}

The investigations were carried out with eight Dorper rams aged between 15 and 18 months. The diet was the same during the investigation, containing ad libitum hay and concentrate $\left(0.30 \mathrm{~kg} \mathrm{day}^{-1}\right)$. At the age of 12 months the rams were maintained in one group while being trained for semen collection with the aid of artificial vagina (AV). Six rams from the initial group could be trained successfully for semen collection, and were involved in the investigation. Occasionally, the rams failed to mount or ejaculate and therefore the number of the samples collected per week differs between the seasons. From May to November 2012 semen was collected once per week from each ram.

\section{Semen collection}

Ejaculates were collected with the aid of an AV filled with $41{ }^{\circ} \mathrm{C}$ water, held in hand and placed in front of the rams as they mounted. A mature ram placed in a neck clamp was used for mounting by the rams. Semen collection vial was removed from $\mathrm{AV}$ and placed into a temperate storage box of $37^{\circ} \mathrm{C}$. After collecting the ejaculates scrotal circumference was measured at the widest point of the testes biweekly.

\section{Semen evaluation}

Semen evaluation was done in the laboratory of the Experimental Farm. Following features of the semen were investigated: volume (ml), density (109), mass (0-5) and progressive motility $(\%)$ and scrotal circumference. The volume of the ejaculate collected was recorded directly from the calibrated test tube. Number of cells was estimated by light scattering at $540 \mathrm{~nm}$ following a dilution 1:400 with physiological saline solution $(0.90 \%$ w/v NaCl), using a MiniTube SDM6 Photometer calibrated to ram semen parameters. Mass motility was estimated under light microscope (10x objective, $37{ }^{\circ} \mathrm{C}$ plate) by investigating non-diluted semen under x100 magnification and the semen samples were characterized with a $0-5$ scale (Evans and Maxwell, 1987). Progressive motility was assessed after diluting semen with physiological saline solution. One drop of the diluted sample was investigated under a cover slip on $37^{\circ} \mathrm{C}$ warm plate by phase-contrast on a pre-warmed glass slide under 400x magnification. Data were subjected to one-way analysis of variance (one-way ANOVA) by using Tukey-test, with the use of SPSS for Windows 15.0.

\section{RESULTS}

Table 1 presents the seminal parameters and scrotal circumference values during the investigation period.

All the average semen parameters were better than the minimum values, described for mature rams.

Table 1.

Average data of semen characteristics and scrotal circumference during the investigation period (02. 05. 2012-31. 10. 2012)

\begin{tabular}{lcccccc}
\hline Volume (ml) & $\begin{array}{c}\text { Density } \\
\left(\mathrm{x} 10^{9} / \mathrm{ml}\right)\end{array}$ & $\begin{array}{c}\text { Total sperm } \\
\text { number/ejaculate } \\
\left(\mathrm{x} 10^{9}\right)\end{array}$ & $\begin{array}{c}\text { Mass motility } \\
(0-5)\end{array}$ & $\begin{array}{c}\text { Progressive } \\
\text { individual } \\
\text { motility }(\%)\end{array}$ & $\begin{array}{c}\text { Scrotal } \\
\text { circumference } \\
(\mathrm{cm})\end{array}$ \\
\hline Mean & 1.3 & 3.61 & 5.21 & 4.0 & 67.0 & 34.8 \\
\pm SEM & 0.5 & 1.47 & 3.25 & 1.0 & 26.3 & 2.8 \\
\hline
\end{tabular}

Semen characteristics of Dorper rams collected in different seasons are presented in Table 2. Significant differences $(\mathrm{P}<0.05)$ were observed in density, total sperm number/ejaculate, and scrotal circumference in the different seasons. Volume was the highest in autumn $(1.4 \pm 0.5 \mathrm{ml})$ and the lowest in the spring $(1.3 \pm 0.4 \mathrm{ml})$. Density was lower in spring $\left(2.7 \pm 1.6 \times 10^{9}\right)$ and summer $\left(3.3 \pm 1.5 \times 10^{9}\right)$ compared to fall $\left(4.1 \pm 1.1 \times 10^{9}\right)$ $(\mathrm{P}<0.05)$. Total sperm number/ejaculate, and scrotal circumference between the seasons differed significantly $(\mathrm{P}<0.05)$.

Table 3 presents the monthly variations of semen characteristics. Monthly fluctuation affected quality and quantity of semen as well. Lower semen volume was observed in June as compared to September $(\mathrm{P}<0.05)$. Sperm concentration was highest in October compared to June $(\mathrm{P}<0.05)$ and an explicit differenc was observed between August and September and from July till October it was a transitional period. It is obvious that increase daylight and average daily temperature had a main influence on sperm concentration. The number of sperm/ejaculate varied among the months. It reached the highest value in September and the lowest in May $(\mathrm{P}<0.05)$. Testicular size is a good indication of sperm producing ability, because sperm production is directly correlated to it. From May to October the value of scrotal circumference constantly increased. The highest value was observed at the beginning of the main breeding season in August.

\section{DISCUSSION}

Evans and Maxwell (1987) described the average values of ram semen parameters. The average ejaculate volumes are ranging between $0.7-2.0 \mathrm{ml}$ with a high sperm density $\left(2-5 \times 10^{9}\right)$. Percentage of motile spermatozoa varies from $30-90 \%$. Regarding semen production all the average semen pameters reached the desired values. Semen volume was $(1.3 \pm 0.5 \mathrm{ml})$ with an average $(3.61 \pm$ $\left.1.47 \times 10^{9}\right)$ concentration and $(67.0 \pm 26.3 \%)$ percentage of motile spermatozoa. Adult rams with a scrotal circumference less than 32 centimeters should not be 
Seasonal variations in semen characteristics and scrotal circumference (Mean \pm SEM)

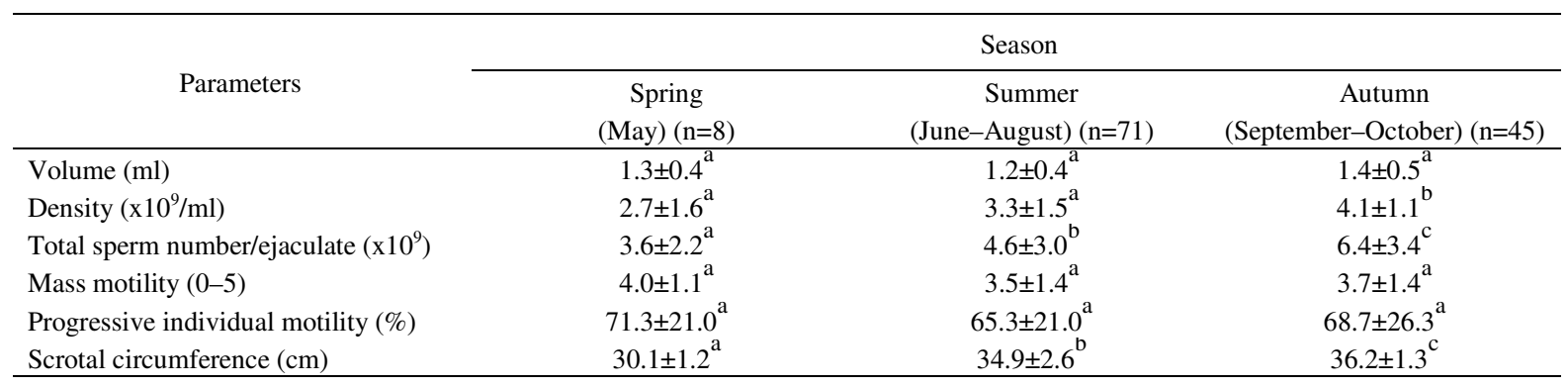

Note: ${ }^{a, b, c}$ means in the column of each parameter with different superscripts differ significantly $(\mathrm{P}<0.05)$.

Table 3.

Monthly variations in semen characteristics and scrotal circumference (Mean $\pm \mathrm{SEM}$ )

\begin{tabular}{|c|c|c|c|c|c|c|}
\hline Month & Volume (ml) & $\begin{array}{l}\text { Density } \\
\left(\mathrm{x} 10^{9} / \mathrm{ml}\right)\end{array}$ & $\begin{array}{c}\text { Total sperm } \\
\text { number/ } \\
\text { ejaculate }\left(\times 10^{9}\right)\end{array}$ & $\begin{array}{l}\text { Mass motiliy } \\
(0-5)\end{array}$ & $\begin{array}{c}\text { Progressive } \\
\text { individual } \\
\text { motility }(\%)\end{array}$ & $\begin{array}{c}\text { Scrotal } \\
\text { circumference } \\
(\mathrm{cm})\end{array}$ \\
\hline June & $1.1 \pm 0.4^{\mathrm{a}}$ & $3.0 \pm 1.2^{\mathrm{a}}$ & $3.50 \pm 2.20^{\mathrm{b}}$ & $3.4 \pm 1.5^{\mathrm{a}}$ & $64.6 \pm 28.5^{\mathrm{a}}$ & $32.8 \pm 2.2^{\mathrm{b}}$ \\
\hline July & $1.4 \pm 0.5^{\mathrm{ab}}$ & $3.8 \pm 1.7^{\mathrm{ab}}$ & $5.61 \pm 3.19^{\mathrm{abc}}$ & $3.9 \pm 1.4^{\mathrm{a}}$ & $70.0 \pm 26.5^{\mathrm{a}}$ & $35.8 \pm 1.6^{\mathrm{c}}$ \\
\hline August & $1.3 \pm 0.6^{\mathrm{ab}}$ & $3.4 \pm 1.6^{\mathrm{ab}}$ & $4.85 \pm 3.30^{\mathrm{abc}}$ & $3.3 \pm 1.4^{\mathrm{a}}$ & $62.6 \pm 26.6^{\mathrm{a}}$ & $36.6 \pm 2.0^{\mathrm{c}}$ \\
\hline October & $1.3 \pm 0.5^{\mathrm{ab}}$ & $4.1 \pm 1.1^{\mathrm{b}}$ & $5.80 \pm 3.21^{\mathrm{abc}}$ & $3.6 \pm 1.6^{\mathrm{a}}$ & $67.3 \pm 29.3^{\mathrm{a}}$ & $36.3 \pm 1.4^{\mathrm{c}}$ \\
\hline
\end{tabular}

Note: ${ }^{a, b, c}$ means in the column of each parameter with different superscripts differ significantly $(\mathrm{P}<0.05)$.

used for breeding. The satisfactory value of testicular size is between $32-40$ centimeters. In this study, the average scrotal circumference was higher $(34.8 \pm 2.8 \mathrm{~cm})$ than the data of Fourie et al. (2004) published (34.1 \pm $0.4 \mathrm{~cm})$, nevertheless it is need to be emphasized that mating and nutrition can override the influence of photoperiod on testicular size (Masters and Fels, 1984). Regarding semen production autumn had a beneficial affect on concentration (x 10 $10^{9}$, total spem number/ ejaculate $\left(\mathrm{x} 10^{9}\right)$ and scrotal circumference. Semen characteristics were generally better during autumn than in spring or summer. Scrotal circumference values also had a subsequent rise from spring to autmn. Several studies have concluded (Boland et al., 1985; Egerszegi et al., 2011; Karagiannidis, 2000; Mandiki et al., 1998; Oláh, 2010) that semen volume, concentration and scrotal cirumference increased during the breeding season. Considering that summer and autumn are seasons with decreasing daylight (breeding season) it is obvious that Dorper rams are sensitive to photoperiodism. The highest ejaculate volume was detected in September and the lowest in May and overall the mean ejaculate volume was the highest in autumn. Several studies concluded that the highest semen volume for rams was observed in autumn and the lowest in spring (Amir and Volcani, 1965; Egerszegi et al., 2011; Oláh, 2010). In this study the highest concentration and sperm number was also in September and similar observations were published by Gundogan and Demirci (2003). The highest mass and progressive motility was in May (however non-significant), while several reports carried out on other breeds concluded (Csiba et al., 2011; Fourie et al., 2004; Karagiannidis et al., 2000; Tajangookeh et al., 2007) that in all year round these values are the lowest in spring (non-breeding season). Cole and Cups (1969) found relationship between high summer temperatures and decreased fertility in sheep. They stated that spermiogenesis is influenced by the scrotal temperature. When scrotal temperature reaches $41^{\circ} \mathrm{C}$ for more than 3 hours it decreases spermiogenesis.

Cupps et al. (1960) and Oláh et al. (2008) also noted that average temperature and the fluctuation in temperature has the biggest influence on semen quality of mature Dorper rams in summer. When the daily average temperature was above $30{ }^{\circ} \mathrm{C}$ the proportion of live spermatozoa was $60-65 \%$ and it did not decreased further more even in the highest temperature. In this study progressive motility was also around $65 \%$ in the summer season. Regarding scrotal circumference there were marked monthly variations. Scrotal circumference was the highest in August, September and October $(36 \mathrm{~cm})$ and the lowest in May $(30 \mathrm{~cm})$, Michelsen et al. (1981) found corresponding results at Suffolk and Lincoln rams. In conclusion the present study showed that semen quality parameteres and scrotal circumference of Dorper rams were better during the autumn months than in the other seasons.

\section{ACKNOWLEDGEMENTS}

We acknowledge the technical assistance of Nikolett Csizmár, Sándor Elek, Lajos Kiss, Imre Nagy, Imre Sass, Judit Sóvágó, István Török and Erika Tőzsérné Hosszú. 
The work/publication is supported by the TÁMOP4.2.2/B-10/1-2010-0024 project. The project is co-financed by the European Union and the European Social Fund.
The thema was supported by the NKPF_07-A32008-02-49 project, Breeding and improving sheep corresponding to the market demands and climate conditions 2008-2010.

\section{IRODALOM}

Amir, D.-Volcani, R. (1965): Seasonal fluctuations in the sexual activity of Awassi, German Mutton Merino, Corriedale, Border Leichester and Dorset Horn rams. II. Seasonal changes in semen characteristics. Journal of Agricultural Science. 64: 121-125.

Boland, M. P.-Al Kamali, A. A.-Crosby, T. F.-Haynes, N. B.-Howles, C. M.-Kelleher, D. R.-Gordon, I. (1985): The influence of breeding season and photoperiod on semen characteristics, testicular size, libido and plasma hormone concentrations in rams. Animal Reproduction Science. 9: 241-252.

Cole, H. H.-Cups, P. T. (1969): Reproduction in Domestic Animals. $2^{\text {nd }}$ edition. New York and London. Academic Press. London. 657.

Csiba A.-Gergátz E.-Gyökér E.-Németh A.-Mihályfi S. (2011): Tavaszi és őszi kossperma mennyiségének, minőségének, valamint mélyhüthetőségének összehasonlítása. 53. Georgikon Tudományos Konferencia. Keszthely. Hungary. 187-197.

Cupps, P. T.-McGowan, B.-Rahlmann, D.F.-Reddon, A. R.-Weir, W. C. (1960): Seasonal changes in the semen of rams. Journal of Animal Science.19: 208-213.

Egerszegi, I.-Sarlós, P.-Molnár, A.-Cseh, S.-Rátky, J. (2011): Semen production of Black Racka rams: effect of season and age. Book of Abstracts of the $62^{\text {nd }}$ Annual Meeting of the European Federation of Animal Science. Stavanger. Norway. 29 August-2 September 2011. Book of Abstracts. 17: 284.

Evans, G.-Maxwell, W. M. (1987): Salamons Artificial Insemination of Sheep and Goats. Butterworth's. Sydney. Australia. 216

Fourie, P. J.-Schwalbach, L. M.-Neser, F. W. C.-Van der Westhuizen, C. (2004): Scrotal, testicular and semen characteristics of young Dorper rams managed under intensive and extensive conditions. Small Ruminant Research. 54: 53-59.

Gergátz E. (2007): A juhok mesterséges termékenyítése. [In: Pécsi T. (szerk.) Házi emlősállatok mesterséges termékenyítése.] Mezőgazda Kiadó. Budapest. 335.

Gundogan, M.-Demirci, E. (2003): Monthly changes in some reproductive parameters and in testosterone and thyroxine values of rams throught one year under continental climate conditions. Deutsche tierärtzliche Wochenschrift. 110: 450-453.

Horváth M. (1983): A kos és a kecskebakok andrológiája. [In: Becze J. (szerk.) A hímivarú állatok szaporodásbiológiája.] Mezőgazdasági Kiadó. Budapest. 180.

Islam, A. B. M. M.-Land, R. B. (1977): Seasonal variation in testis diameter and sperm output of rams of breeds of different prolificacy. Animal Production. 3: 311-317.
Lategan, D. (2004): Dorpers. Into the new century. Brochure \& Training Manual. Dorper Sheep Breeders' Society of SA, \& Dolf Lategan. 5-9.

Kafi, M.-Safdarian, M.-Hashemi, M. (2004): Seasonal variation in semen characteristics, scrotal circumferance and libido of Persian Karakul rams. Small Ruminant Research. 54: 133-139.

Karagiannidis, A.-Varsakeli, S.-Alexopoulos, C.-Amarantidis, I. (2000): Seasonal variation in semen characteristics of Chios and Friesian rams in Greece. Small Ruminant Research. 37: 125-130.

Kovács, A.-Kukovics, S.-Jávor, A. (2008): Dorpers, the meat sheep of the future. Analele Universita din Oradea. Fascicula: Ecotoxicologie, Zootechnie si Technologii de Industrie Alimentara. 7. 7: 272-275.

Mandiki, S. N. M.-Derycke, G.-Bister, J. L.-Paquay, R. (1998): Influence of season and age of sexual maturation parameters of Texel, Suffolk and Ile de France rams: 1. Testicular size, semen quality and reproductive capacity. Small Ruminant Research. 28: 67-79.

Masters, D. G.-Fels, H. E. (1984): Seasonal changes in the testicular size of grazing rams. Animal Production in Australia. 15: 444447.

Mickelsen, W. D.-Paisley, R. G.-Dahmen, J. J. (1981): The effect of season on scrotal circumference and sperm motility and morphology in rams. Theriogenology. 16: 45-51.

Milne, C. (2000): The history of the Dorper sheep. Small Ruminant Research. 36: 99-102.

Net 1: www.sheep101.info

Oláh J. (2010): A juhondó minőségét befolyásoló tényezők. Debreceni Egyetem Állattenyésztési Tudományok Doktori Iskola. $\mathrm{PhD}$ értekezés. 42-47.

Oláh J.-Fazekas G.-Vass N.-Pécsi A.-Kovács A.-Jávor A. (2008): Dorper kosok nyáron végzett ondóvizsgálata. [In: Kukovics S.Jávor A. (szerk.) A juhtenyésztés jelene és jövője az EU-ban. Licium Art Kiadó. Debrecen. 337-346.

Sarlós, P.-Molnár, A. (1995): Seasonal changes in sperm parameters of British Milk sheep rams. Acta Veterinaria Hungarica. 43: 247-257.

Székely, T. (2011): Dorper sheep have attractive properties. The Organic Farmer. 68: 3.

Tajangookeh, H. D.-Shahneh, A. Z.-Shahrebabak, M. M.-Shakeri, M. (2007): Monthly variation of plasma concentrations of testosterone and thyroid hormones and reproductive characteristics in three breeds of Iran fat-tailed rams throught one year. Pakistan Journal of Biological Science. 10: 3420-3424. 